\title{
Estratégias Bancárias Diferenciadas no Território: - Caso de Minas Gerais
}

\section{Regional Bank Strategy: the Case of Minas Gerais}

\author{
Mara Nogueira* \\ Marco Crocco** \\ Ana Tereza Lanna Figueiredo ${ }^{* * *}$
}

\begin{abstract}
Resumo: Este artigo objetiva investigar em que medida existem no Estado de Minas Gerais estratégias bancárias diferenciadas no território. Com base na concepção pós-keynesiana de preferência pela liquidez distinta por região (DOW, 1993), analisa-se o balanço consolidado das agências bancárias de 351 municípios mineiros, divididos em cinco grupos. Através da análise de indicadores, construídos a partir do citado balanço, conclui-se que existem evidências a assinalar o fato de o sistema bancário mineiro atuar de forma diferenciada no espaço, comportamento esse que reforça as desigualdades regionais.
\end{abstract}

Palavras-chave: Estratégia bancária. Economia regional. Bancos.

Abstract: The aim of this paper is to investigate in what extent there is a differentiated regional bank strategy in the economy of Minas Gerais. Based on the post-Keynesian theory of regional liquidity preference (DOW, 1993), the article analyses the consolidate balance sheet of bank's branches in 351 cities of Minas Gerais, divided in five different groups. Through the analyses of some of the indicators that has been built using the balance sheet, the paper concludes that there are evidences that supports the statement that the state's Bank System works in a different way over the space. This behavior reinforces the uneven regional patterns of development in its economy.

Keywords: Bank's strategy. Regional economy. Banks.

JEL Classification: G21; O16; O18; R11.

\footnotetext{
* Mestranda em Economia do CEDEPLAR/UFMG e pesquisadora do grupo LEMTe (Laboratório de Estudos em Moeda e Território), CEDEPLAR/UFMG. E-mail: maracnt@cedeplar.ufmg.br

** Professor adjunto do Centro de Desenvolvimento e Planejamento Regional (CEDEPLAR)/ UFMG e coordenador do grupo LEMTe.E-mail: crocco@cedeplar.ufmg.br

*** Professora-assistente do Departamento de Ciências Econômicas da PUC Minas. Doutoranda do CEDEPLAR/UFMG e pesquisadora do grupo LEMTe. E-mail: lanna@cedeplar.ufmg.br
} 


\section{Introdução}

A literatura sobre a questão regional brasileira tem se caracterizado por estudos focados no comportamento das variáveis reais da economia (produção, emprego, salários etc.). Variáveis monetárias e financeiras são frequentemente negligenciadas. Este fato é justificado, em parte, pela ausência de fontes de dados satisfatórias para a análise regional da perspectiva financeira e monetária (AMADO, 1998, p. 418). No entanto, apesar destas limitações, alguns trabalhos (AMADO, 1997, 1998; CROCCO; JAYME JR., 2006) mostraram que é possível extrair importantes conclusões a partir do estudo deste campo de investigação. Dentro deste contexto, insere-se o presente artigo.

O objetivo proposto aqui é o de investigar em que medida existem no Estado de Minas Gerais estratégias bancárias diferenciadas no território. Com base na concepção pós-keynesiana de preferência pela liquidez distinta por região (DOW, 1993), analisa-se o balanço consolidado das agências bancárias de todos os municípios mineiros com dados disponíveis para o período de 1989 a 2004. A amostra abrange 351 cidades divididas em cinco grupos, tendo como critério o PIB gerado pelas localidades em 2005. Através da análise de indicadores construídos para esses grupos a partir do citado balanço, conclui-se que existem evidências a assinalar o fato de o sistema bancário mineiro atuar de forma diferenciada no espaço, comportamento esse que reforça as desigualdades regionais.

A seção seguinte (II) expõe brevemente o entendimento pós-keynesiano da dinâmica regional. A terceira seção descreve a evolução recente do sistema bancário brasileiro de forma a captar suas transformações e consequentes impactos sobre estratégias bancárias gerais. A seção IV, cerne do artigo, investiga a existência de estratégias bancárias diferenciadas no território. Na última seção, algumas conclusões são apresentadas.

\section{Moeda e Espaço na Perspectiva Pós-Keynesiana}

O pouco destaque dado à moeda e ao seu papel para o desenvolvimento das regiões constitui uma característica marcante na literatura acerca de economia regional. Vários modelos de determinação da renda regional, como o neoclássico, o de causação cumulativa e o de insumoproduto, não consideram o impacto da moeda e de variáveis financeiras. Quando abordadas, tais variáveis são, em sua maioria, tratadas em modelos econométricos, nos quais algumas variáveis monetárias nacionais, consideradas exógenas, afetam a determinação regional da renda em 
função das características específicas de cada localidade. Assim, a moeda e os fluxos monetários têm sido considerados como resultado da diferença entre as áreas e não como a causa desta diferença.

Segundo Rodríguez-Fuentes (1998; 2006), as principais razões para tal ausência de referências a fatores monetários são: 1) a hipótese ortodoxa de que a moeda é neutra no longo prazo e, assim sendo, não pode explicar valores reais no âmbito nacional, nem tampouco no contexto regional; 2) o fato de regiões não usarem instrumentos de política monetária, e, portanto, estes serem sem importância para estudo; 3) o fato de regiões serem muito abertas e possuírem perfeita mobilidade de capital, fazendo com que a oferta de moeda seja horizontal.

A neutralidade das variáveis financeiras é assumida pelo mainstream em economia, para quem a renda real depende apenas de fatores reais. Neste contexto, a moeda é vista apenas como um véu que facilita as trocas e ajusta o nível geral de preços. Os bancos, por sua vez, são também considerados neutros, pois somente alocam poupanças disponíveis entre projetos alternativos. Regionalmente, o sistema bancário somente afetará o desempenho das variáveis reais quando fracassar na alocação do crédito nacional entre diferentes regiões, devido à presença de falhas de mercado, tais como informação imperfeita ou assimétrica e custos de transação. ${ }^{1}$ Quando nenhum desses problemas ocorrerem, o mercado de crédito regional atuará de forma apropriada e equilibrará o fluxo financeiro inter-regional, fazendo com que as regiões não enfrentem problemas financeiros, pois deparar-se-ão com uma curva de oferta de crédito perfeitamente elástica.

Embora as raízes de diferenças de renda regionais possam ser atribuídas a fatores estruturais, variáveis monetárias podem ser responsáveis pela manutenção e ampliação das diferenças de renda regional quando se adota uma abordagem em que a moeda e os bancos não são neutros para o desenvolvimento regional. Trabalhos nesta linha de abordagem, de cunho pós-keynesiano, surgiram nas últimas décadas na literatura econômica. ${ }^{2}$

A teoria monetária pós-keynesiana considera a moeda como uma parte integrante do processo econômico e, dessa forma, não é possível distinguir claramente o lado monetário do lado real da economia (DOW, 1993). Para os pós-keynesianos, a moeda não é exógena, entrando no

1 Roberts e Fishkind (1979), Moore e Hill (1982) são autores de trabalhos que tentaram identificar fatores que poderiam levar ao racionamento de crédito em mercados regionais. Recentemente, autores da linha neo-keynesiana como Faini et al (1993) e Samolyk (1994) têm explorado o argumento da informação assimétrica nos mercados de crédito regional.

2 Para um estudo empírico desta teoria em nível internacional, ver Dow (1990). Ver Amado (1997), para a aplicação ao caso brasileiro. 
sistema econômico através do crédito gerado pelos bancos e induzido pela sua demanda.

A análise pós-keynesiana também se distingue das demais por abordar tanto o lado da oferta quanto o lado da demanda no mercado de crédito regional. Para esses autores, a oferta e a demanda de crédito são interdependentes e afetadas pela preferência pela liquidez, vinculada às expectativas que os agentes formam em um ambiente de incerteza. Do ponto de vista dos bancos, a preferência pela liquidez afetará negativamente a sua disposição em emprestar na região, caso possuam expectativas pessimistas ou pouco confiáveis sobre a mesma. No lado da demanda por crédito, a preferência pela liquidez do público afetará suas respectivas definições de portfólio. Quanto maior a preferência pela liquidez, maiores as posições em ativos líquidos destes agentes e menor sua demanda por crédito.

A partir de tais conceitos teóricos e utilizando-se de elementos da Teoria da Causação Cumulativa e da Dependência, Dow (1982; 1993) apresenta alguns modelos em que o sistema financeiro, juntamente com o lado real da economia, pode promover padrões de desenvolvimento regional desiguais. Dow (1982) tenta traduzir os argumentos de liquidez para um contexto espacial.

Dois casos extremos de regiões com diferenças em suas características são considerados: uma região central e uma periférica. O centro seria uma região próspera, com mercados ativos e sofisticação financeira. A periferia seria uma economia estagnada, com tênues mercados e um menor grau de sofisticação financeira. O modelo considera que, mesmo dentro de uma nação, as inovações financeiras somente estendem-se do centro financeiro para regiões mais remotas após certo lag de tempo e que custos de transações adicionais e de informação ajudam a preservar esta diferença. Como resultado dessas características, a preferência pela liquidez seria maior na periferia, a liquidez de qualquer ativo seria maior no centro do que na periferia e, no longo prazo, o multiplicador bancário seria maior no centro. Além disso, a contextualidade espacial permite que o agente possa manter, simultaneamente, ativos de economias de várias regiões, implicando não só a endogeneização espacial da base monetária, como também reforçando o caráter distinto das ofertas de moeda regionais. ${ }^{3}$

Dow (1982) trabalha com um sistema bancário de base regional. Entretanto, seus argumentos de diferenças na oferta de moeda continuam válidos em um sistema bancário nacional, em que o fluxo de capitais pode ser exacerbado e a destinação das alocações dos recursos depende crucialmente das decisões do centro, para onde o capital flui e os níveis de depósitos são maiores. 
O centro é definido como um local que apresenta uma estrutura produtiva historicamente dominada pela indústria e pelo comércio e onde se situa o centro financeiro. A periferia, por sua vez, concentra suas atividades no setor primário e nas manufaturas de baixa tecnologia, com uma dinâmica econômica centrada na exportação para o centro, sendo as receitas de suas vendas sensíveis à conjuntura no centro e, consequentemente, altamente voláteis. O centro possui spread effects sobre a periferia, não apenas nas suas demandas de produtos, mas também na difusão de tecnologia, mão de obra qualificada e serviços através de suas filiais, promovendo uma dependência do centro pela periferia.

Tais características implicam que a preferência pela liquidez será maior na periferia para os seus residentes, sejam bancos, empresários ou público. As razões para tal seriam o alto risco de perda de capital para os bancos, relacionados ao risco de default dos empréstimos; a mudança da eficiência marginal do investimento para as empresas, que é afetada pela menor disponibilidade de empréstimos e maiores juros bancários; e a incerteza na obtenção de renda percebida pelo público, ambos ligados à volatilidade da economia.

Como resultado, bancos nacionais acabam por emprestar menos para a periferia, dada a sua estrutura econômica e o remoto controle sobre as suas filiais. Bancos específicos da periferia, por sua vez, preferirão manter um nível de reservas mais altos e restringir os empréstimos locais, colocando-se em uma posição de desvantagem relativa e encorajando a concentração bancária no centro. Além disso, a maior preferência pela liquidez do público na periferia se traduzir-se-ia em maior parcela de depósitos à vista sobre depósitos a prazo, o que poderia levar os bancos a alterarem a composição de seus portfólios ajustando-o ao menor prazo dos depósitos.

Fundamental, para o presente trabalho, é entender que a abordagem teórica adotada aqui abre a possibilidade de os bancos e/ou suas agências seguirem estratégias diferenciadas no território. Investigar essa possibilidade é o objetivo central do artigo, o que será feito a partir da análise do caso brasileiro.

\section{A Evolução do Sistema Bancário nos Anos 1990}

A estratégia de atuação dos bancos é definida pela busca contínua de adequação do seu portfólio de ativos a uma relação entre rentabilidade e liquidez que acreditam ser a ideal, frente à conjuntura econômica vigente e às expectativas que têm sobre o futuro, dado o ambiente institucional. Neste contexto, a análise de estratégias bancárias diferen- 
ciadas no território brasileiro será feita. Para tanto, esta seção destina-se a sistematizar as mudanças ocorridas no sistema bancário brasileiro, iniciadas no final dos anos 80 que se estenderam até recentemente.

O processo de reestruturação do setor bancário no Brasil pode ser explicado por dois movimentos, um interno e outro externo ao país. O primeiro teve início em meados da década de 1990, com o fim do processo inflacionário, determinando o término do chamado floating. ${ }^{4}$ Isto fez com que os bancos fossem obrigados a mudar suas estratégias de atuação, aumentando o peso de créditos concedidos em seu ativo.

O segundo movimento pode ser entendido como a adoção tardia no país das propostas do chamado Consenso de Washington, que implicou abertura do setor bancário e sua desregulamentação, aliado ao programa de privatizações dos bancos públicos, notadamente os estaduais. Tais fatos contribuíram para fomentar a concentração bancária no país, refletindo duas tendências simultâneas: a) concentração geográfica das agências e; b) onda de fusões e aquisições.

A primeira relaciona-se diretamente com o fim dos ganhos do floating. Durante o período inflacionário, os bancos beneficiaram-se grandemente das receitas inflacionárias. Esta receita, gerada pelo significativo spread nominal entre taxas passivas e ativas de juros, obtida principalmente nos depósitos à vista, representava uma importante fonte de recursos. Em função deste mecanismo, a estrutura operacional dos bancos foi montada para maximizar a captação de depósitos (CARVALHO; STUDART; ALVES JR., 2002). Essa estratégia encontrava respaldo na diretriz do Banco Central, que naquela época objetivava uma maior capilaridade do atendimento bancário. Isto implicou a abertura de uma grande quantidade de agências em diversos municípios brasileiros.

A partir de julho de 1994, entretanto, com a implantação do Plano Real (plano de estabilização da economia), observou-se uma rápida queda da inflação. O novo ambiente macroeconômico gerou profundas consequências para o funcionamento do sistema bancário, uma vez que extinguiu sua principal fonte de rentabilidade. Inicialmente, os bancos responderam à perda das receitas inflacionárias com o aumento das operações de crédito - concentrado nos empréstimos ao consumidor e ao comércio - e com a adoção de uma postura financeira mais ousada, aproveitando-se, assim, do forte crescimento da demanda.

A rápida e intensa expansão do crédito, em condições de acirrada concorrência entre os bancos por aumento de receita e ampliação de

$4 \quad$ Floating: lucro obtido pelos bancos, resultante da diferença entre os depósitos não indexados ou recolhimento de tributos e os ganhos que obtinham investindo estes recursos (BARBACHAN; FONSECA, 2004). 
mercados, só foi possível graças a um significativo relaxamento da avaliação de riscos. Assim, observou-se um forte aumento na inadimplência (SOARES, 2001). Além disso, cabe lembrar que a diminuição do ritmo de crescimento da economia no $2^{\circ}$ trimestre de 1995 , decorrente da adoção pelo governo brasileiro de uma política monetária e creditícia altamente restritiva devido à crise mexicana do fim de $1994,{ }^{5}$ elevou enormemente os créditos em atraso e em liquidação (PUGA, 1999). Assim, em um segundo momento, os bancos passaram a adotar uma postura mais defensiva, expressão de sua maior preferência pela liquidez e pela segurança. Direcionaram então suas carteiras para ativos de menor risco, em especial, títulos públicos, bem remunerados ao longo do período.

Cabe lembrar que os bancos compensaram parte da receita perdida (fim do floating) com a redução das despesas administrativas, em especial as de pessoal, e com o incremento de novas fontes de receitas - particularmente as provenientes das tarifas bancárias (SOARES, 2001). De fato, de acordo com estudo do IBGE, a receita de serviços quase que duplicou sua participação relativa nos anos posteriores ao Plano Real. Passou de 8\%, em 1990, para 10,5\%, em 1993, e para 21,5\%, em 1995 (ANDIMA-IBGE, 1997).

A segunda tendência, a de fusões e aquisições, foi consequência tanto do movimento anteriormente descrito quanto dos importantes incentivos concedidos pelo governo, mediante a implantação de dois programas de reforma do sistema financeiro: o PROER (Programa de Estímulo à Reestruturação e ao Fortalecimento do Sistema Financeiro Nacional) e o PROES (Programa de Incentivo à Redução do Setor Público Estadual na Atividade Bancária). Também fundamental para o processo foi a abertura do sistema bancário à participação estrangeira, especialmente a partir de 1995. Todos esses programas inserem-se numa agenda mais ampla de liberalização econômica e redução do papel do estado na economia, nos moldes sugeridos pelo já mencionado Consenso de Washington.

O PROER, criado em novembro de 1995, autorizava o Banco Central a disponibilizar recursos para que instituições financeiras sólidas adquirissem o controle acionário de bancos em dificuldades resultantes do novo ambiente macroeconômico vigente. Já o PROES foi criado em fevereiro de 1997, com o mesmo objetivo, mas focado na promoção do saneamento financeiro dos bancos estaduais para fins de privatização. Ambos os programas definiram importantes instrumentos institucionais para a reestruturação do setor bancário brasileiro. Além disso,

5 O Banco Central do Brasil elevou as taxas de juros para evitar a saída de capitais do país. 
contribuíram para o propósito governamental de reduzir a presença dos bancos públicos, por viabilizarem as privatizações (CARVALHO; STUDART; ALVES JR., 2002).

Finalmente, resta ressaltar que o processo de reestruturação bancária determinou também a eliminação de praticamente todos os bancos de caráter regional - reconhecidamente os mais vulneráveis. Acentuaram-se, portanto, as restrições financeiras das regiões, prejudicando o seu desenvolvimento.

Como pode-se constatar, o cenário macroeconômico vigente e o ambiente institucional implicaram diferentes estratégias adotadas pelos bancos. De forma geral, pode-se delinear um comportamento padrão para o setor bancário brasileiro nos diferentes períodos analisados. Entretanto, acredita-se que os bancos apresentem táticas de atuação diferenciadas por região. A hipótese assumida é a de que a preferência pela liquidez é distinta no espaço. Assim sendo, o seu comportamento também o é. No próximo item, será mais bem detalhada a estratégia dos bancos em cada grupo de municípios.

\section{Estratégias Bancárias Diferenciadas no Espaço: o Caso de Minas}

Neste trabalho, serão analisados apenas 351 dos 853 municípios mineiros. Isso ocorre em função de apenas estas cidades terem pelo menos uma agência bancária entre 1989 e 2004 e, portanto, apresentarem dados financeiros para o período.

Com o objetivo de facilitar a análise das cidades selecionadas, optou-se por dividir os 351 municípios mineiros em grupos, tomando como referência o Produto Interno Bruto (PIB) de 2005. ${ }^{6}$ Dessa forma, as cidades foram agregadas em cinco faixas, a saber: (i) localidades com PIB inferior a $\mathrm{R} \$ 50$ milhões; (ii) localidades com PIB entre $\mathrm{R} \$ 50$ milhões e $\mathrm{R} \$ 200$ milhões; (iii) localidades com PIB entre $\mathrm{R} \$ 200$ milhões e $R \$ 600$ milhões; (iv) localidades com PIB superior a $R \$ 600$ milhões; e, (v) localidades pertencentes à microrregião de Belo Horizonte.

Ao agregar municípios com peso econômico semelhante, tem-se como hipótese subjacente o fato de o sistema bancário guiar suas estratégias - tanto de localização quanto de alocação de recursos - em parte, com base nessa variável, suposição esta que se buscará provar ao longo do texto. A opção de isolar em grupos as cidades pertencentes à microrregião de Belo Horizonte se justifica pela influência que a capital mineira exerce na região do seu entorno. Tais localidades passam, dessa

$6 \quad$ PIB em Reais, a preços constantes de 2000. Série fornecida pelo IBGE e disponível no site do Ipeadata (BRASIL, 2008). 
forma, a apresentar características peculiares em função de sua localização privilegiada e possuem, portanto, um peso econômico superior à sua participação no PIB mineiro.

\subsection{Base de Dados}

Serão utilizados diversos índices ${ }^{7}$ que têm por objetivo fornecer informações para a identificação de uma estratégia bancária diferenciada no espaço mineiro. Esses foram construídos a partir de contas selecionadas do ativo e passivo de todos os bancos com carteira comercial em atividade no Brasil. O Quadro 1 a seguir apresenta os indicadores.

O grupo formado pelos três primeiros indicadores - Fin.Ativo, Emp. Ativo e Tvm.Ativo - tem como objetivo delinear o tipo de atuação que o sistema bancário tem em determinado município. Ou seja, a forma como os ativos bancários são alocados de maneira a aproveitar as oportunidades de lucro. Assim, um alto valor para Tvm.Ativo indica um perfil de ação baseado em aplicações especulativas no mercado financeiro e em títulos públicos. Já uma proporção elevada de empréstimos sobre o total do ativo (Emp.Ativo) sugere uma atuação centrada em empréstimos de curto prazo, voltados principalmente para empresas (capital de giro) e consumo. Por fim, uma concentração no financiamento da atividade produtiva através dos créditos de longo prazo seria captada pelo índice Fin.Ativo.

\begin{tabular}{|c|c|}
\hline Indicadores & Descrição \\
\hline Fin.Ativo & Total de Financiamentos sobre o Total do Ativo \\
\hline Emp.Ativo & Empréstimos e Títulos Descontados sobre o Total do Ativo \\
\hline Tvm.Ativo & Títulos e Valores Mobiliários sobre o Total do Ativo \\
\hline Lucro.Ativo & Lucro sobre o Total do Ativo \\
\hline Ativo.PIB & Total do Ativo sobre PIB Municipal \\
\hline PLB & Preferência pela liquidez dos Bancos \\
\hline IRC & Índice Regional de Crédito \\
\hline
\end{tabular}

Quadro 1 - Indicadores

Fonte: Elaborado pelos autores.

O quarto indicador, Lucro.Ativo, mede a remuneração do setor bancário por unidade do ativo aplicado no município. Pretende-se, a partir dessa variável, verificar os resultados da estratégia bancária de

7 Para a elaboração dos índices, foi utilizado o banco de dados do Laboratório de Estudos em Moeda e Território (LEMTe/Cedeplar), cuja origem é a Estatística Bancária Mensal disponibilizada desde 1988 pelo Banco Central. 
alocação dos ativos, em termos de rentabilidade do mesmo, captando diferenças regionais.

Já o Ativo.PIB é um índice que reflete o peso do sistema bancário na estrutura produtiva do município. Dessa forma, uma alta participação do ativo dos bancos no total de riqueza gerada em uma localidade significa um sistema financeiro mais consolidado.

$\mathrm{A} \mathrm{PLB}^{8}$ é uma proxy para a preferência pela liquidez dos bancos nas diferentes cidades. E calculado da forma que se segue:

$$
\mathrm{PLB}=\text { Depósito à vista/Crédito Total }
$$

- Dep. a vista: soma das médias anuais das contas Dep. vista do Governo e Dep. vista do Setor Privado

- Crédito total: somatório de Empréstimos e Títulos Descontados e das contas Financiamentos.

De acordo com Cavalcante (2006), esta última relação capta a magnitude em que o banco opta por disponibilizar seus ativos de maior prazo em relação a suas obrigações mais imediatas. As contas utilizadas refletem respectivamente a intenção do público em manter seus ativos o mais líquido possível (Dep. à Vista) e a intenção dos bancos em emprestar, ou seja, reduzir a liquidez de seus ativos (Crédito Total). Dessa forma, quanto maior o índice, mais alta a preferência pela liquidez dos bancos em uma determinada região. Isto pode ser reflexo de uma alta proporção de depósitos em relação ao crédito (indicando uma indisponibilidade do setor bancário em alongar o prazo de suas obrigações) ou de uma decisão dos bancos em conceder pouco crédito, mantendo seus ativos mais líquidos.

Por fim, o Índice Regional de Crédito é a razão entre a participação relativa de um município no total de créditos concedidos no estado e a participação relativa desta mesma cidade no PIB mineiro.

$$
\mathrm{IRC}=\text { (Crédito Total município/Crédito Total MG/ } / \text { PIB munic/MG) }
$$

Desta forma, caso um município apresente IRC superior a 1 , isso indicará que a concessão de crédito na região é maior do que poderia ser esperado em função da riqueza existente no local (PIB). E, caso tenha valor abaixo de 1, menor. Sendo assim, um IRC alto sugere uma participação importante do sistema bancário como financiador da atividade produtiva e um valor baixo para o índice reflete um sistema financeiro pouco comprometido com o financiamento da economia.

Este indicador foi criado por Crocco et al. (2005). 


\subsection{O Tamanho Regional do Sistema Bancário em Minas Gerais}

Existe uma literatura relativamente ampla e recente que versa sobre o relacionamento entre desenvolvimento do sistema financeiro e crescimento (KING; LEVINE, 1993a; 1993b; 1993c; et al.). Entre as variáveis utilizadas para medir esta relação, o indicador Ativo/PIB é um dos mais utilizados, ${ }^{9}$ uma vez que nos dá a dimensão do sistema financeiro na economia local. A Tabela 1 mostra o peso diferenciado do sistema bancário mineiro captado a partir desse indicador.

Tabela 1 - Ativo/PIB

Cidades Mineiras: 1990 a 2004

\begin{tabular}{c|c|c|c|c|c}
\hline \multirow{2}{*}{ Anos } & \multicolumn{5}{|c}{ PIB (milhões de R\$) } \\
\cline { 2 - 6 } & $<50$ & 50 a 200 & 200 a 600 & $>600$ & Micro BH \\
\hline 1990 & 0,17 & 0,20 & 0,22 & 0,26 & 2,93 \\
\hline 1991 & 0,13 & 0,15 & 0,20 & 0,22 & 2,58 \\
\hline 1992 & 0,13 & 0,15 & 0,19 & 0,22 & 6,33 \\
\hline 1993 & 0,11 & 0,14 & 0,18 & 0,28 & 8,33 \\
\hline 1994 & 0,14 & 0,17 & 0,22 & 0,35 & 7,91 \\
\hline 1995 & 0,20 & 0,27 & 0,35 & 0,59 & 2,64 \\
\hline 1996 & 0,20 & 0,25 & 0,34 & 0,41 & 1,32 \\
\hline 1997 & 0,26 & 0,32 & 0,39 & 0,55 & 1,47 \\
\hline 1998 & 0,17 & 0,23 & 0,26 & 0,24 & 1,49 \\
\hline 1999 & 0,18 & 0,23 & 0,28 & 0,28 & 1,45 \\
\hline 2000 & 0,18 & 0,23 & 0,27 & 0,29 & 1,45 \\
\hline 2001 & 0,27 & 0,37 & 0,42 & 0,38 & 2,61 \\
\hline 2002 & 0,26 & 0,34 & 0,37 & 0,38 & 2,95 \\
\hline 2003 & 0,23 & 0,29 & 0,31 & 0,33 & 2,79 \\
\hline 2004 & 0,24 & 0,29 & 0,29 & 0,29 & 2,92 \\
\hline
\end{tabular}

Nota: Os dados até 2000 são disponibilizados pela Fundação João Pinheiro, e, a partir de 2001, utilizam-se dados do IBGE. Dada a diferença de metodologia utilizada pelas duas instituições, devem-se considerar as duas séries de forma isolada.

Fonte: LEMTe, Fundação João Pinheiro e IBGE.

9 Para uma análise de indicadores de avaliação do sistema financeiro, ver World Bank e International Monetary Fund (2005). 
Os dados ilustram de forma clara o peso diferenciado da microrregião de Belo Horizonte - centro financeiro do Estado - em comparação com os demais grupos de municípios. É possível perceber que, durante o período 1990-2000, as hierarquias de desenvolvimento financeiro e o peso econômico dos municípios coincidem. Apenas em 1999, tem-se um valor igual para os municípios do segundo e terceiro grupos $(0,28)$, o que reforça a hipótese de que existe uma alta correlação entre o peso econômico de um município - medido pelo PIB - e seu grau de desenvolvimento financeiro - medido pelo indicador Ativo/PIB. Nota-se também que apenas a microrregião de $\mathrm{BH}$ apresenta valor superior a 1 (um) durante todo o período, o que significa que, neste grupo, o sistema financeiro aloca um volume de recursos superior ao produto interno bruto gerado pelos mesmos. Em última instância, sugere uma drenagem de recursos para a microrregião belorizontina.

A observação dos dados também permite alguns comentários sobre a estratégia de atuação dos bancos em Minas Gerais ao longo dos anos analisados. Tem-se que, de 1991 a 1993, a concentração de recursos na microrregião de $\mathrm{BH}$ é crescente, em detrimento das demais, chegando a um pico de 8,33 em comparação com 0,11 do grupo de municípios menos desenvolvidos. Tais valores coincidem com o período inflacionário, no qual os bancos auferiam vultosos lucros com o floating. Este fato ficará claro mais adiante com a análise de outros indicadores, mostrando que essa forte concentração de recursos na micro de $\mathrm{BH}$ deve-se, principalmente, à aplicação em títulos e valores mobiliários. No período de 1994 a 1996, observa-se uma queda do indicador para a microrregião de Belo Horizonte e uma elevação para os demais grupos de municípios, o que representa uma mudança de estratégia dos bancos. Com o fim do floating, eles passaram a emprestar mais e de forma mais desconcentrada no espaço, como forma de compensar a perda das receitas inflacionárias.

A partir de 1996, o indicador estabiliza-se para a micro belorizontina ${ }^{10} \mathrm{e}$, no entanto, observa-se uma forte queda para os demais grupos de municípios entre 1997 e 1998, o que coincide com a crise cambial brasileira. Isto demonstra que a opção dos bancos foi a de reduzir a alocação de ativos nos municípios menos desenvolvidos, nos quais o grau de risco das aplicações é maior, mantendo as aplicações na cidade de $\mathrm{BH}$ e em seu entorno, onde o retorno das aplicações é mais garantido.

10 De 1994 para 1995, observa-se uma queda bastante considerável no indicador Ativo/PIB para a micro de BH, esta queda está associada a uma redução no Ativo guiada por contas que não são alvo de estudo neste trabalho. 
O resultado encontrado acha-se em consonância com a literatura internacional que versa sobre o relacionamento entre desenvolvimento do sistema financeiro e crescimento econômico (GERTLER; ROSE, 1996; RAJAN; ZINGALES, 1998; LEVINE, 1997; 1998; et al.). ${ }^{11}$ Ainda que não haja um consenso sobre a direção de causalidade, há concordância de que o relacionamento existe.

A discussão que se faz necessária neste momento é procurar entender em que medida esta diferença no grau de desenvolvimento do sistema bancário é fruto de uma ação deliberada dos bancos ou não. Neste sentido, procurar-se-á, na seção seguinte, identificar a existência ou não de estratégias bancárias diferenciadas no espaço.

\subsection{Estratégias Bancárias Regionais}

A identificação de estratégias bancárias diferenciadas no espaço não é uma tarefa trivial. Em primeiro lugar, existe uma clara deficiência relativa à disponibilidade de informações em escala regional, notadamente no Brasil. Em segundo lugar, dado o elevado grau de integração existente entre as regiões, sempre há a possibilidade de uma ação em uma região específica ser fruto de fatos ocorridos em outras regiões, e não naquela que está sendo analisada. Este fato é ainda mais relevante no caso brasileiro, no qual o sistema bancário é composto basicamente por grandes bancos nacionais, com agências espalhadas por todo o país, e com quase nenhum banco regional. Apesar disso, acredita-se que fortes indicações possam existir no sentido de identificação destas estratégias, mesmo levando-se em conta as considerações supracitadas. Assim sendo, foram elaborados vários indicadores que devem ser considerados em conjunto para a identificação destas estratégias.

1) Preferência pela Liquidez dos Bancos

A preferência pela liquidez dos bancos (PLB) constitui o primeiro indicador a ser analisado. Esse indicador mede a maior ou menor disposição dos bancos em se manter mais ou menos líquidos, sendo calculado dividindo-se o mais líquido dos itens do seu passivo (total dos depósitos à vista) pelo item menos líquido do seu ativo (total dos créditos concedidos). Assim, quanto maior o indicador, maior a preferência pela liquidez do banco, ou seja, menor a sua disposição em emprestar. O Gráfico 1 mostra a evolução da PLB nos municípios mineiros divididos por intervalos de PIB e para a microrregião de BH no período de 1989 a 2004.

11 Ver, dentre outros, Demetriades e Hussein (1996), Arestis e Demetriades (1997) e Jayaratne e Strahan (1996). 


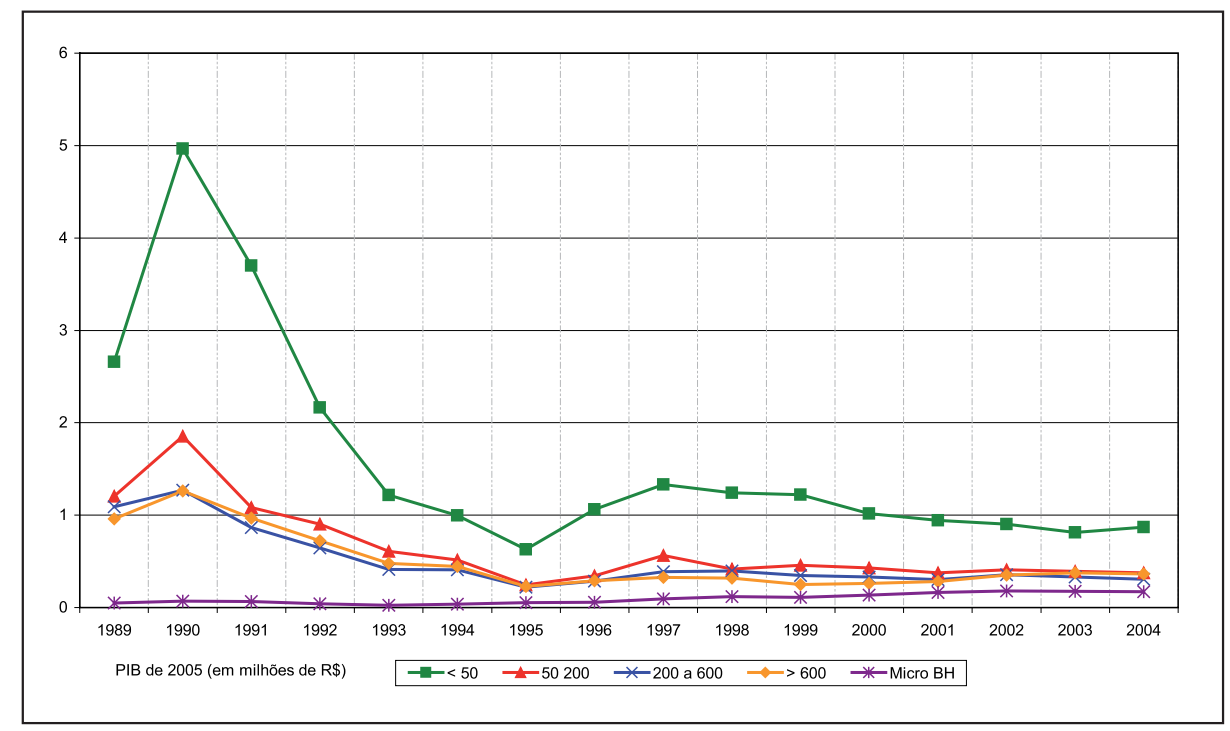

Gráfico 1 - Preferência pela Liquidez dos Bancos Cidades Mineiras: 1989 a 2004

Fonte: LEMTe/Cedeplar.

Ele permite duas análises. Em primeiro lugar, o resultado confirma a teoria pós-keynesiana, segundo a qual em regiões mais atrasadas a preferência pela liquidez tende a ser maior. De acordo com esta abordagem, os locais menos desenvolvidos economicamente apresentam maior incerteza sobre o futuro, o que leva os agentes lá instalados (bancos e público, de uma forma geral) a buscarem ativos mais líquidos como forma de proteção. Assim, a preferência pela liquidez nestas regiões é maior. Por outro lado, nas áreas mais desenvolvidas (regiões centrais) há maior disposição tanto para demandar como para ofertar crédito - reflexo de uma menor preferência pela liquidez dos agentes (DOW, 1993).

De fato, durante toda a série, os municípios com PIB inferior a $\mathrm{R} \$ 50$ milhões (menos desenvolvidos) apresentaram os maiores níveis de PLB e a microrregião de $\mathrm{BH}$ (a mais desenvolvida) os menores. ${ }^{12}$

Em segundo lugar, o Gráfico mostra que o indicador apresentou comportamento semelhante em todos os grupos de municípios durante o período analisado. Observa-se que, entre 1990 e 1995, há uma tendência generalizada de queda da preferência pela liquidez dos bancos. Em um primeiro momento, esta constatação causa estranheza. Era de se esperar que, em períodos inflacionários - como é o caso -, houvesse um aumento da preferência pela liquidez dos agentes como um todo, em virtude do ambiente de elevada instabilidade. Entretanto, dada a forma como é calculado o índice, o resultado faz sentido. Em épocas de aceleração dos

12 Este resultado corrobora os obtidos por Crocco et al (2005), que utilizaram dados somente até 2002. 
preços, as pessoas reduzem o montante de depósitos à vista efetuados. Elas optam por aplicações que rendam algum tipo de juros, a fim de tentar ao menos manter o poder de compra de suas moedas. Sendo assim, o numerador da expressão é reduzido, diminuindo a expressão como um todo. Além disso, apesar da instabilidade, deve ser lembrado que, até 1994, todas as operações financeiras no Brasil utilizavam-se da correção monetária como mecanismo de proteção contra a inflação, inclusive as operações de crédito. Isto contribuía para dar uma maior garantia a esse tipo de operação. Assim, pode-se afirmar que, apesar da inflação elevada, as operações de empréstimos continuavam sendo feitas considerando-se apenas os fatores reais.

A trajetória da PLB na microrregião de $\mathrm{BH}$ é crescente em todo o período pós-estabilização, enquanto nas demais regiões é possível observar uma elevação do indicador no período 1995-1997 - que pode ser resultado do fechamento massivo de agências, opção estratégica dos bancos frente ao fim do floating - e uma tendência de queda após 1997, com posterior estabilização da preferência pela liquidez dos bancos. Tal fato pode ser explicado por uma maior desconcentração espacial do crédito, cujo volume diminui na microrregião belorizontina, aumentando nas demais, como poderá ser visto na análise de outros indicadores. Vale ressaltar que o aumento no volume de crédito no Estado deveu-se à elevação dos empréstimos concedidos, uma vez que os financiamentos mantiveram-se praticamente estáveis ao longo da série, como observa-se através da análise do Gráfico 2.

Nas palavras de Crocco e Santos (2006),

Com a estabilização monetária pós-1994, acreditou-se que o sistema bancário pudesse exercer a sua função central de financiamento da atividade produtiva, uma vez que era esperado que o setor público não mais necessitasse financiar seu déficit (CROCCO; SANTOS, 2006, p. 49).

De fato, houve um significativo aumento do crédito logo no início do Plano Real, mas, como pode ser visto no Gráfico 2, o aumento foi liderado pelos empréstimos, geralmente recursos de curto-prazo com juros mais altos. Enquanto isso, o volume de financiamentos concedidos no Estado apresentou uma queda pós-estabilização e permaneceu praticamente constante durante o período 1996-2003. 


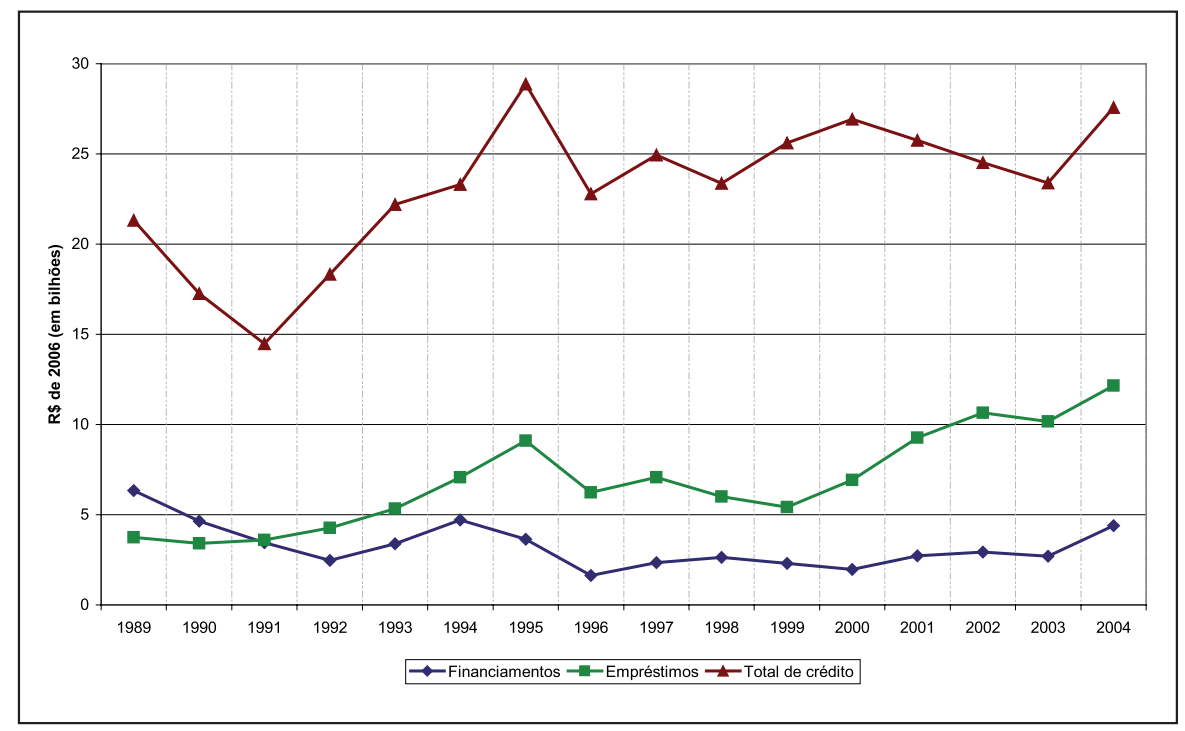

Gráfico 2 - Volume de Crédito em MG: 1989 a 2004 Fonte: LEMTe/CEDEPLAR.

A partir da observação do Gráfico, constata-se também que o volume de crédito apresenta um pico em 1995 e passa a decair, com leve recuperação em 1997, até o ápice da crise mexicana em 1998. Tal fato pode ser compreendido como um resultado da reinstalação de uma política monetária de juros elevados, implementada em resposta às turbulências na economia, geradas por fatores externos (crise mexicana e, posteriormente, as contagiadas economias emergentes). Esse fato "voltou a proporcionar aos bancos uma aplicação financeira mais rentável e menos arriscada do que a concessão de crédito" (CROCCO; SANTOS, 2006, p. 50).

2) A Distribuição Regional do Crédito

Como pode-se observar no Gráfico 3, existe uma forte concentração regional do crédito no Estado, delineando o mesmo quadro hierárquico observado nos indicadores já analisados. 


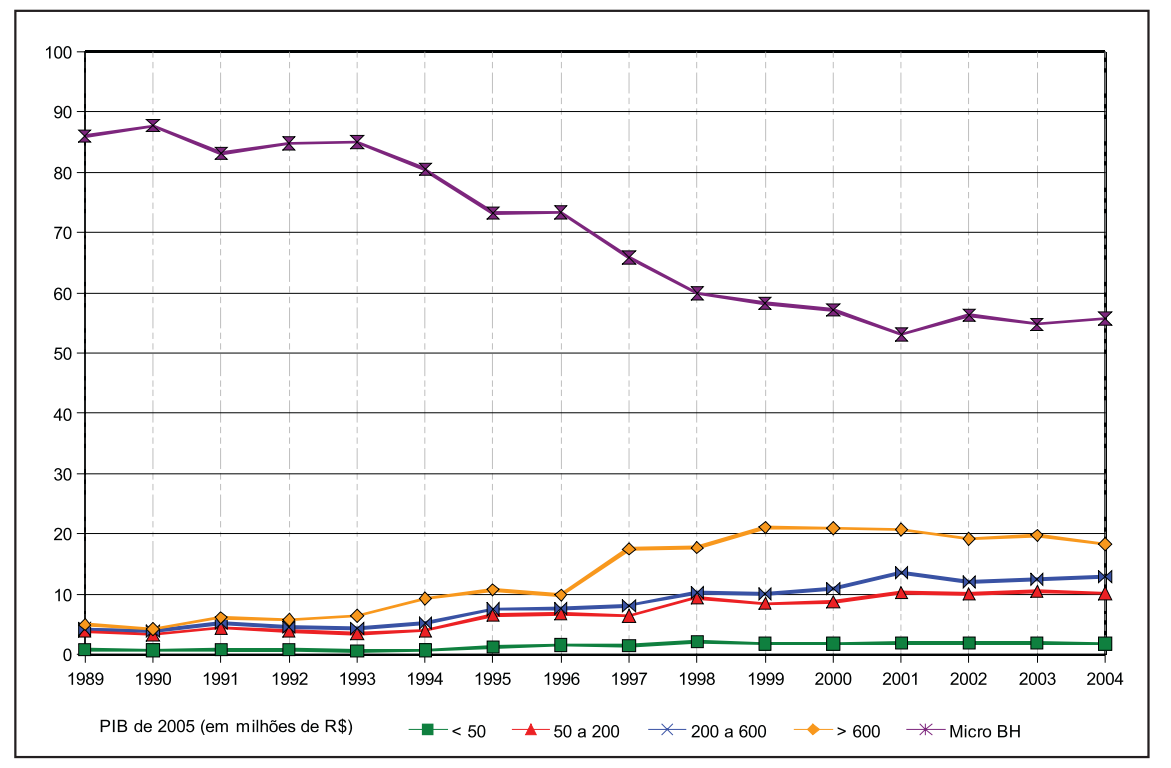

Gráfico 3 - Distribuição Regional do Crédito

Cidades Mineiras: 1989 a 2004

Fonte: LEMTe/Cedeplar.

Em toda a série, observa-se uma correspondência entre peso econômico e grau de participação no volume de crédito concedido, fato este que acaba reforçando as disparidades regionais. Em todo o período pesquisado, a microrregião de Belo Horizonte apresentou uma participação relativa na distribuição regional acima de 50\%, atingindo em 1990 um pico de quase 90\% de todo o crédito concedido no Estado. Por sua vez, os municípios de menor peso econômico (com PIB inferior a $\mathrm{R} \$ 50$ milhões) atingiram, em 1998, a sua participação máxima: 2,2\%. Contudo, a análise do gráfico reforça o que foi dito anteriormente. No período que se seguiu ao plano Real, houve uma tendência à desconcentração espacial do crédito. Enquanto a micro de BH apresentou uma queda quase ininterrupta no volume de crédito concedido após 1993, nos demais grupos de municípios, a trajetória foi ascendente, principalmente daquele ano em diante, coincidindo com a queda observada para a micro belorizontina. Entretanto, como será visto posteriormente, a redução do crédito concedido em $\mathrm{BH}$ e no entorno é mais do que compensada pelas aplicações em títulos e valores mobiliários, cuja alocação é concentrada quase que completamente nesses municípios.

Cabe ressaltar que, nas cidades menos desenvolvidas, o aumento do crédito deu-se principalmente através da expansão dos empréstimos, em detrimento dos financiamentos. Esta opção do setor bancário deve-se a dois fatores: a) risco mais baixo do empréstimo em relação ao financiamento, associado aos prazos mais curtos e valores menores; 
$\mathrm{e}, \mathrm{b})$ retornos mais altos, fruto das taxas de juros mais altas praticadas nesta modalidade.

3) Índice Regional de Crédito

Pode-se argumentar que a concentração espacial do crédito seja apenas um reflexo do peso econômico dos municípios. De fato, é de se esperar que regiões com maiores PIBs apresentem uma demanda por crédito mais elevada e, dessa forma, uma maior participação relativa na distribuição deste.

No entanto, o que se defende aqui é que existe uma relação de causação circular cumulativa ${ }^{13}$ entre volume de crédito e desenvolvimento econômico. Localidades de maior dinamismo econômico seriam mais atrativas à instalação de agências, enquanto aqueles municípios de economia menos desenvolvida não teriam acesso a serviços financeiros mais sofisticados. Dessa forma, enquanto os municípios desenvolvidos, com acesso a crédito e a serviços financeiros sofisticados, cresceriam ainda mais, os municípios desassistidos, sem recursos para se desenvolver, estariam fadados ao subdesenvolvimento econômico.

$\mathrm{O}$ indicador, aqui chamado de Índice Regional de Crédito (IRC), calculado a partir da razão entre a participação relativa de um grupo de municípios no total de crédito concedido em Minas e a participação relativa desta mesma região no PIB estadual ${ }^{14}$ destaca se a concessão de crédito em determinado grupo é maior do que o que poderia ser esperado em função da riqueza existente na região (PIB). Dessa forma, tem-se um índice que, quando superior a 1 , sugere que os municípios recebem uma fatia dos empréstimos e financiamentos concedidos no Estado que é maior do que sua contribuição para o PIB mineiro, e naqueles com valor abaixo de 1 ocorre o inverso.

13 Para compreender melhor o conceito de causação circular cumulativa ver Myrdal (1960).

14 Este indicador é uma adaptação do quociente locacional amplamente utilizado na literatura de economia regional para determinar a existência ou não de especialização produtiva em uma região específica. 


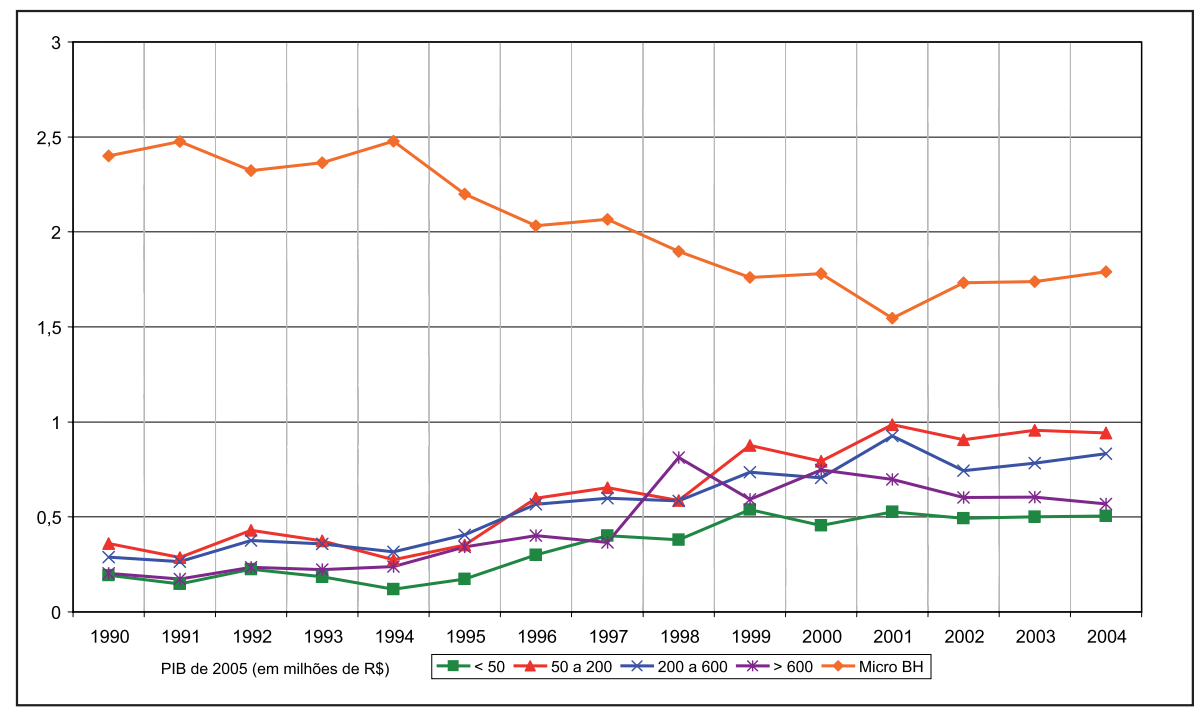

Gráfico 4 - Índice Regional de Crédito (\%Crédito/\%PIB)

Cidades Mineiras: 1990 a 2000

Nota: Os dados até 2000 são disponibilizados pela Fundação João Pinheiro, a partir de 2001, utilizam-se dados do IBGE.

Fonte: LEMTe/Cedeplar, Fundação João Pinheiro e IBGE.

A evolução do Índice Regional de Crédito é mostrada no Gráfico 4. Fica evidente que, durante todo o período de análise, todos os grupos de municípios, à exceção da micro belorizontina, tiveram uma participação na distribuição do crédito inferior a suas respectivas contribuições para o PIB do Estado. Apenas a micro de BH fica acima de 1 durante todo período e, apesar de registrar queda no indicador até 2001, após 2002, a tendência é de relativa estabilidade. Os demais grupos de municípios apresentam uma tendência ascendente pós-1994, o que é condizente com as análises dos demais índices que denotam uma ampliação da concessão de crédito nos municípios interioranos, em detrimento da capital e seu entorno.

Um outro dado interessante revelado pelo gráfico é que a hierarquia de municípios - tão clara nos demais gráficos e tabelas analisadas até aqui - é rompida. No caso do IRC, os municípios de PIB entre $\mathrm{R} \$ 50$ e $R \$ 200$ milhões apresentam os melhores resultados - excetuando a micro belorizontina - sendo superados apenas em dois momentos: o primeiro entre 1994 e 1996, pelos municípios com PIB entre $R \$ 200$ e $\mathrm{R} \$ 600$ milhões, e o segundo pelos municípios com PIB superior a $\mathrm{R} \$ 600$ milhões. Já a comparação entre estes últimos revela vantagem em quase todo o período para os primeiros. Tal constatação, em princípio contrassensual, apenas reforça uma hipótese que vem se firmando na análise contemporânea da dinâmica regional mineira, a saber: os municípios de 
menor porte vêm apresentando um desempenho econômico superior àquelas cidades de economia mais desenvolvida e consolidada. ${ }^{15}$

4) Gestão do Ativo Bancário

Passa-se agora ao estudo sobre a gestão do ativo dos bancos nos diferentes municípios mineiros. Serão analisadas quatro variáveis: Lucro/Ativo, Empréstimos (Emp)/Ativo, Financiamentos (Financ)/Ativo e Títulos e Valores Mobiliários (Tvm)/Ativo. ${ }^{16} \mathrm{O}$ índice Lucro/Ativo permite avaliar a capacidade do sistema bancário em transformar os seus direitos e haveres, representados por seu ativo, em lucro. Em outras palavras, ele capta a capacidade da gestão do ativo em gerar ou não lucros. Os outros três indicadores procuram identificar com maior detalhe qual conta do ativo bancário pode estar melhor contribuindo para o resultado observado no índice anterior. Por simplificação, optou-se por trabalhar com apenas três contas do ativo: Empréstimos, Financiamentos e Títulos. Estes seriam, teoricamente, os ativos de menor liquidez e maior rentabilidade (crédito: empréstimos e financiamentos) e de maior liquidez e menor rentabilidade (títulos) - excetuando-se a retenção de moeda na sua forma mais líquida - cash. ${ }^{17}$

No caso das operações de crédito, optou-se por analisar de forma diferenciada os empréstimos e os financiamentos, partindo da compreensão de que as duas formas de crédito têm retornos diferenciados para o banco, em termos de rentabilidade do ativo. Além disso, têm papéis distintos na dinâmica do desenvolvimento regional. A diferença encontra-se no fato de os juros cobrados nos empréstimos - crédito na maioria das vezes de curto prazo e voltado para consumo - serem mais elevados do que aqueles praticados nos financiamentos - crédito de longo prazo, mais associado a investimentos. Dessa forma, os empréstimos têm uma rentabilidade maior, na medida em que geram uma fração de lucro superior à proporção de recursos despendidos na operação. O financiamento, como já foi dito anteriormente, tende a ser mais concentrado no espaço por ser uma modalidade de empréstimo mais arriscada. Além de envolver, via de regra, montantes mais expressivos - destina-se a investimentos - seu retorno depende diretamente

15 Ver Pereira (2002).

16 No caso do TVM/Ativo, apenas os municípios com PIB superior a $\mathrm{R} \$ 600$ milhões e a micro de $\mathrm{BH}$ registram valores para esse indicador, isso ocorre porque a aplicação em títulos, por ser um serviço financeiro mais sofisticado, é registrada apenas em municípios com um setor financeiro mais desenvolvido.

17 É importante ressaltar que as operações de crédito e a aplicação em títulos não são as únicas fontes de lucro de um banco. Hoje em dia, especialmente, um importante componente da sua receita é obtido a partir dos serviços prestados, das taxas bancárias. Entretanto, essas informações não estão disponíveis de maneira regionalizada, motivo pelo qual não serão utilizadas no trabalho. 
do sucesso de uma atividade econômica. Dessa forma, em tese, quanto mais desenvolvida é uma localidade, menor o risco envolvido em uma operação de financiamento, maior tende a ser a concessão de financiamento, comparativamente a regiões menos desenvolvidas. Tal fato acaba desencadeando um mecanismo de causação circular cumulativa que estimula as desigualdades regionais, dada a importância do financiamento para o desenvolvimento econômico.

O Gráfico 5 apresenta a evolução do Lucro/Ativo dos bancos, por grupo de municípios, entre 1989 e 2004. Em quase todo o período analisado, principalmente após a estabilização monetária, observa-se que o sistema bancário dos municípios menos desenvolvidos mostrou-se relativamente mais lucrativo do que o da microrregião de Belo Horizonte - a mais desenvolvida economicamente. Isto ocorre a despeito destes municípios emprestarem proporcionalmente menos que os seus PIBs (haja vista o IRC), devido em grande parte à maior preferência pela liquidez dos bancos e de apresentarem relativamente pequeno peso nos respectivos PIBs (Ativo/PIB). Tal fato sinaliza que a relativamente pequena intermediação financeira, realizada pelo sistema bancário nestas regiões, não interfere na obtenção de lucros pelo mesmo.

Este dado, quando analisado em conjunto com as tabelas e com os gráficos anteriores, aponta claramente para a existência de estratégias diferenciadas no espaço. A hipótese implícita no mainstream da economia é que a eficiência microeconômica leva, automaticamente, à alocação ótima de recursos e à eficiência macroeconômica (CARVALHO; STUDART; ALVES JR., 2002). Entretanto, nem sempre é assim. Um sistema bancário microeconomicamente eficiente não conduz necessariamente a um maior volume de crédito e a uma melhor eficiência em sua alocação. Os bancos definem suas estratégias de atuação (realização de operações de empréstimos, financiamentos e/ou aplicações em títulos), buscando adequar suas carteiras de ativos a uma relação entre rentabilidade e liquidez que julgam ser a melhor. Tal atitude é tomada considerando-se as expectativas dos bancos sobre o futuro, definindo a sua preferência pela liquidez. Portanto, não necessariamente maior lucratividade está associada à concessão maior de crédito.

Contudo, no caso específico de Minas, a análise conjunta dos indicadores sugere que essa maior rentabilidade dos ativos registrada nos municípios de menor peso econômico está muito ligada à maior concessão de empréstimos e a sua desconcentração no espaço, observada no período pós-Plano Real.

Pelo Gráfico 5, constata-se que a variável Lucro/Ativo na capital mineira e no entorno apresentou a tendência mais estável em comparação com os demais grupos. Entre 1990 e 1994, tem-se uma trajetória 
de queda. A partir de então, mostra-se ascendente até que os lucros tornam-se positivos em 1998. A persistência de lucros negativos entre 1990 e 1998 pode ser explicada pelo fato de Belo Horizonte - por se constituir no centro financeiro do Estado - registrar um número de operações que não necessariamente foram efetuadas ali e, portanto, poder contabilizar prejuízos de operações efetuadas em outras localidades.

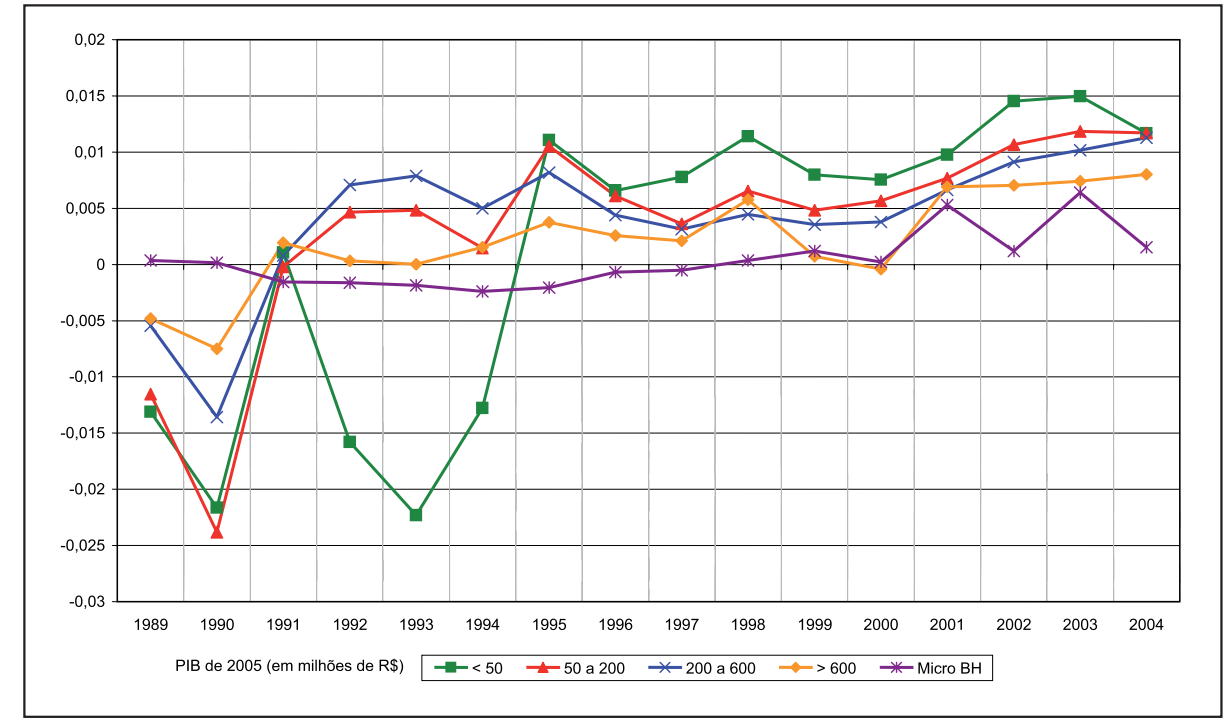

Gráfico 5 - Lucro/Ativo

Cidades Mineiras: 1989 a 2004

Fonte: LEMTe/CEDEPLAR.

Observa-se ainda que parece haver uma correlação positiva entre o peso econômico dos municípios e o nível de oscilação do indicador. Este caráter mais instável do lucro/ativo nos municípios menos desenvolvidos sugere que em períodos de turbulência econômica o sistema bancário modifica sua estratégia, retira recursos de municípios onde as aplicações constituem um risco maior e mantém suas aplicações em municípios maiores, mais desenvolvidos e, portanto, com menores riscos. Este fato é condizente com a teoria pós-keynesiana que sustenta que regiões periféricas têm padrão mais instável de criação de crédito em relação às centrais, ditado pelas diferentes preferências pela liquidez dos agentes (RODRÍGUEZ-FUENTES, 1998).

Percebe-se que, num primeiro momento, houve uma queda acentuada no indicador para os municípios menos desenvolvidos que vai até 1993, enquanto que os demais grupos mantêm uma trajetória crescente, à exceção dos municípios com PIB superior a $R \$ 600$ milhões, nos quais o indicador apresenta uma leve queda entre 1991 e 1993 e na micro de $\mathrm{BH}$, onde o índice é relativamente constante. Percebe-se que, a partir 
de 1993, a tendência inverte-se, sendo que os municípios com PIB entre $\mathrm{R} \$ 50$ e $\mathrm{R} \$ 600$ milhões sofrem uma queda na lucratividade de seus ativos.

De 1994 a 1995, a trajetória é crescente para todos os grupos de municípios, o que corresponde ao aumento da participação do crédito no ativo dos bancos, como pode ser visto mais adiante. De 1995 até 1997, a trajetória é descendente para todos os grupos, exceto para os municípios menos desenvolvidos e os da micro de $\mathrm{BH}$. No caso dos primeiros, a recuperação do indicador ocorre em 1996, mantendo-se crescente até 1998, quando uma série de crises externas atinge o setor. Já no caso da microrregião belorizontina, a trajetória é levemente ascendente no período que vai de 1994-1999. Tal resultado ficará mais claro com a análise da participação dos títulos e valores mobiliários no ativo dos bancos.

Outros aspectos que podem explicar o crescimento do lucro nos municípios mineiros e que também fazem parte do processo de readaptação dos bancos ao cenário pós-estabilização são: de um lado, a expressiva redução de custos levada a cabo pelo setor, com investimentos em tecnologia, ampliação dos canais de autoatendimento, redução do número de agências e corte de gastos com pessoal e, por outro, a ascensão das tarifas como uma fonte significativa de recursos.

A seguir, será apresentada uma série de cinco gráficos, um para cada grupo de municípios, nos quais foram plotados conjuntamente com o lucro/ativo, os indicadores Emp/ativo, Financ/ativo - para o caso dos cinco grupos - e Tvm/ativo, para o caso dos municípios com PIB superior a $\mathrm{R} \$ 600$ milhões e para a microrregião de Belo Horizonte. A partir da análise destes gráficos, pretende-se compreender o comportamento do indicador lucro/ativo à luz das principais aplicações geradoras de receitas para os bancos, a saber: créditos (financiamentos e empréstimos) e aplicações em títulos e valores mobiliários. 


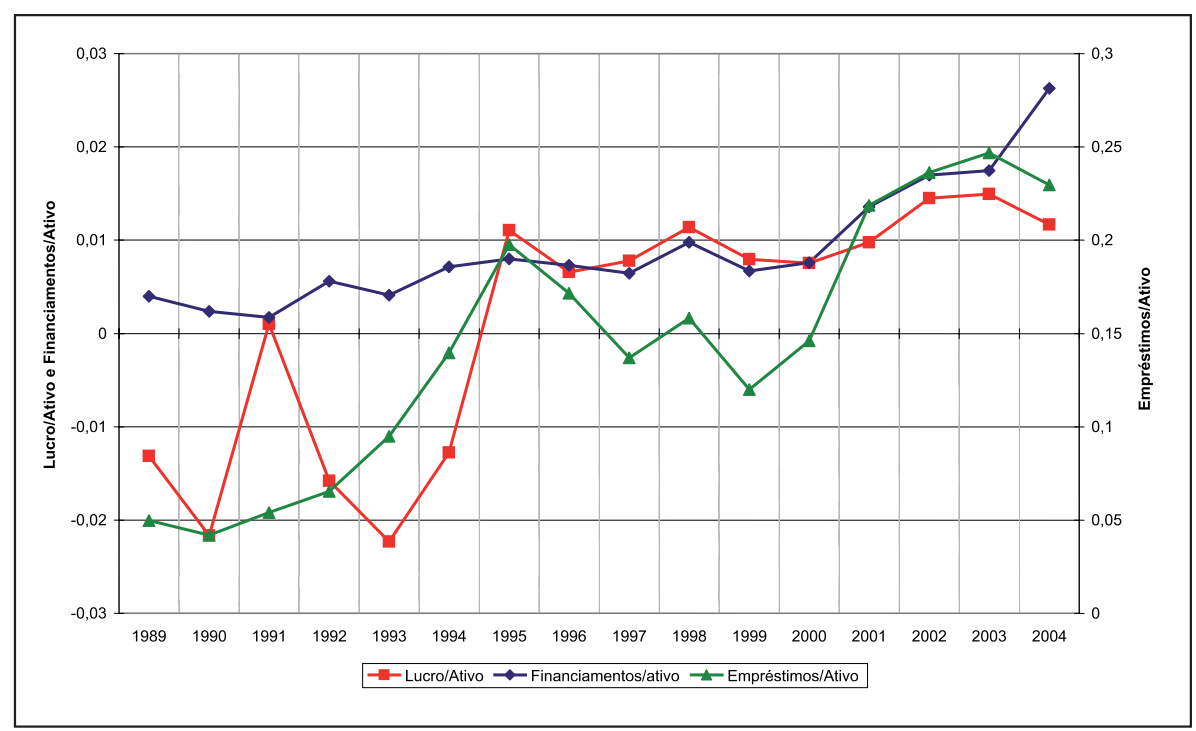

Gráfico 6 - Gestão do Ativo

Municípios com PIB até R\$50 milhões: 1989 a 2004

Fonte: LEMTe/Cedeplar.

A análise do Gráfico 6 sugere que a rentabilidade do ativo nas regiões menos desenvolvidas foi bastante influenciada pela concessão de crédito, especialmente considerando-se o período após 1994. Os empréstimos desempenharam um papel mais relevante, na medida em que o próprio volume de empréstimos, em termos de ativo nessas localidades, é bem superior à proporção de financiamentos, ainda que este tenha apresentado tendência crescente.

A proporção de empréstimos sobre o ativo foi crescente até 1995, quando começa a declinar. Este é justamente o comportamento do Lucro/Ativo. Entre 1997 e 1998, o indicador Emp/Ativo registra outra elevação. Em seguida, sofre queda, retomando a trajetória de crescimento até 2003. A tendência é a mesma observada para a rentabilidade do ativo no período, demonstrando a correlação existente entre os indicadores. 


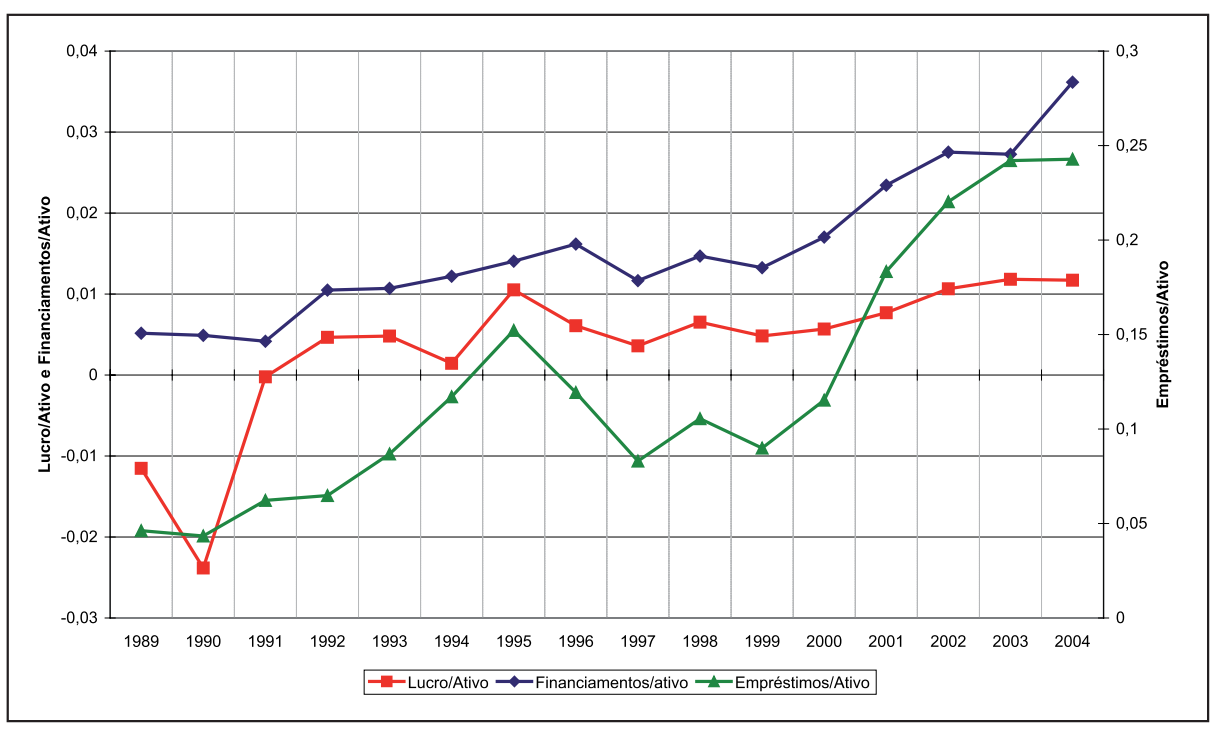

Gráfico 7 - Gestão do Ativo

Municípios com PIB entre $\mathrm{R} \$ 50$ e $\mathrm{R} \$ 200$ milhões 1989 a 2004

Fonte: LEMTe/Cedeplar.

Nota-se, pelo Gráfico 7, que a mesma correspondência descrita anteriormente repete-se para o caso dos municípios com PIB entre $\mathrm{R} \$ 50$ e $\mathrm{R} \$ 200$ milhões. O comportamento do indicador Lucro/Ativo acompanha, em boa parte, a tendência observada para o índice empréstimos/ativo. Ressalte-se que os empréstimos representavam cerca de $5 \%$ do ativo desses municípios em 1989, enquanto que a proporção de financiamentos não chegava a 1\% no mesmo ano. Já em 2004, enquanto os empréstimos atingiram quase $1 / 4$ das aplicações, os financiamentos alcançaram cerca de 3,5\%. Dessa forma, embora a tendência de ambos os índices - empréstimos e financiamentos sobre o ativo - sejam crescentes, com trajetórias semelhantes durante a série analisada, a representatividade maior do primeiro sugere sua maior importância.

O Gráfico 8 mostra que, nos municípios de médio porte, o comportamento dos indicadores Emp/Ativo e Financ/Ativo é semelhante e ambos parecem ter influência sobre a rentabilidade dos ativos. 


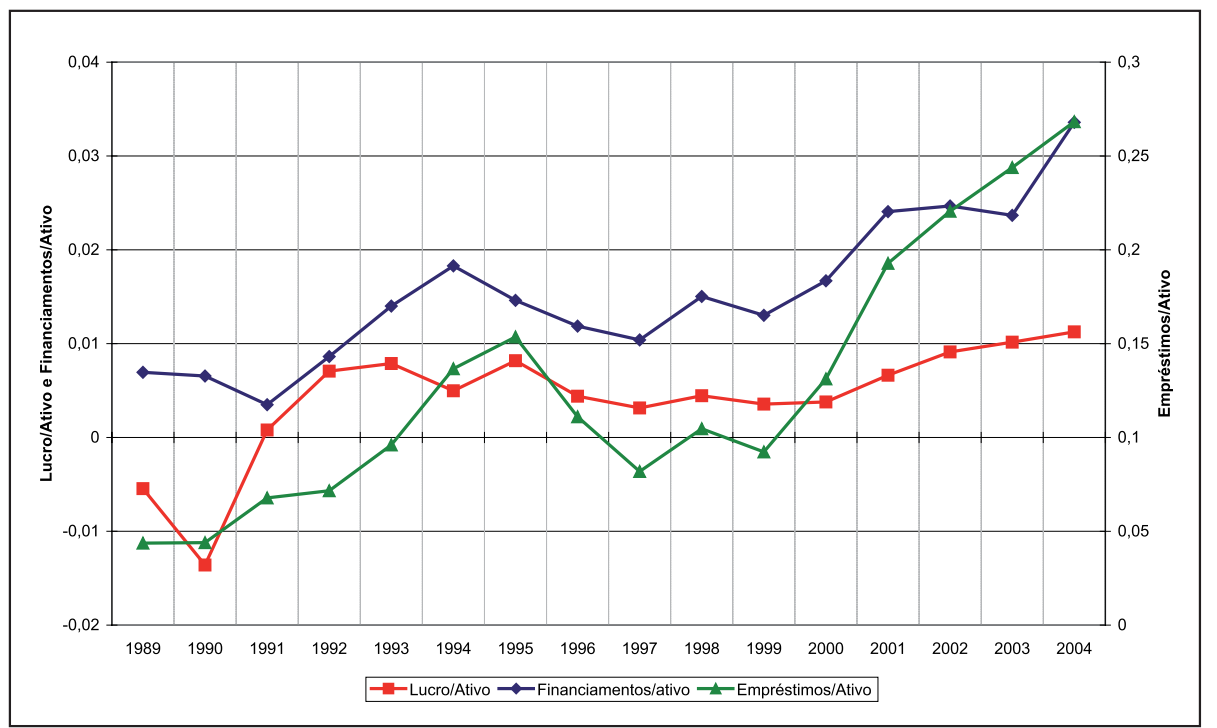

Gráfico 8 - Gestão do Ativo

Municípios com PIB entre R $\$ 200$ e R $\$ 600$ milhões: 1989 a 2004

Fonte: LEMTe/Cedeplar.

Verifica-se também que o comportamento dos indicadores reproduz, em grande medida, a tendência observada para os grupos de municípios descritos anteriormente, sugerindo uma estratégia semelhante do sistema financeiro para os municípios mineiros, ainda que com diferentes graus de intensidade.

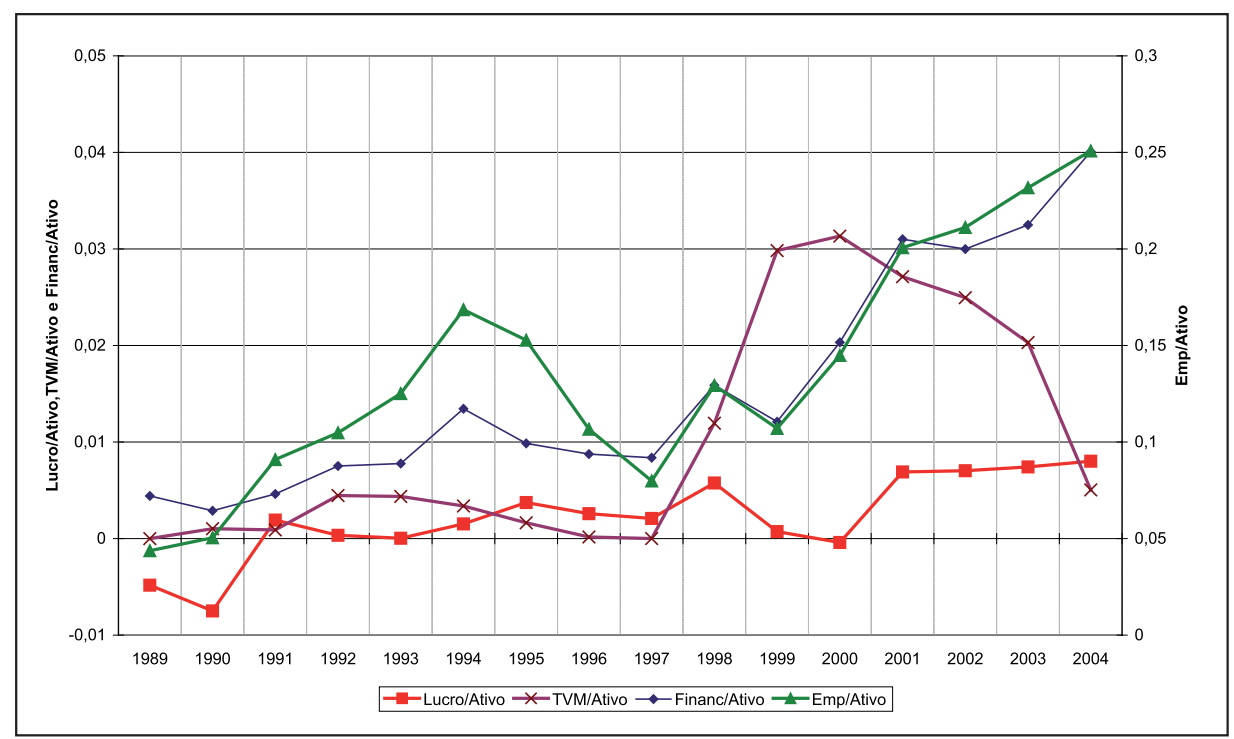

Gráfico 9 - Gestão do Ativo

Municípios com PIB superior a R \$600 milhões: 1989 a 2004

Fonte: LEMTe/Cedeplar. 
No caso dos municípios com PIB superior a $\mathrm{R} \$ 600$ milhões, a proporção dos lucros sobre o ativo parece ser correlacionada com a proporção de financiamentos sobre o total de aplicações (Gráfico 9). Nestes municípios já é possível observar que certa parte do ativo é investida em títulos e valores mobiliários. No entanto, o comportamento deste indicador não acompanha a trajetória do Lucro/Ativo e não parece importante para explicar seu comportamento.

No Gráfico 10, observam-se os dados relativos à gestão do ativo nos municípios pertencentes à micro belorizontina.

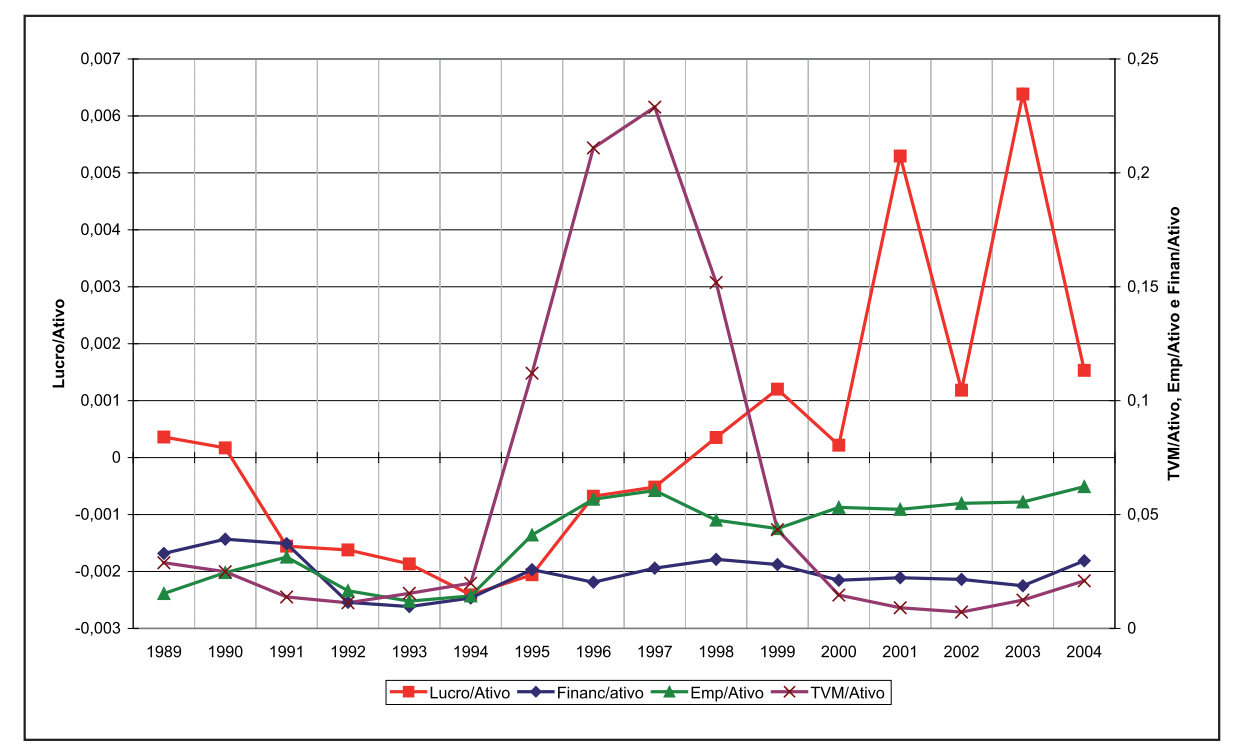

Gráfico 10 - Gestão do Ativo

Municípios da Microrregião de Belo Horizonte: 1989 a 2004

Fonte: LEMTe/Cedeplar.

A análise da trajetória do Lucro/Ativo para estas localidades demonstra que, ao contrário dos demais grupos de municípios, nos quais é possível identificar qual aplicação ativa do banco está influenciando seu desempenho, neste caso, as tendências da rentabilidade do ativo apresentam um comportamento mais complexo. Belo Horizonte, por tratar-se do centro financeiro de Estado, registra tanto um volume quanto uma gama de operações muito mais variadas do que o restante dos municípios mineiros.

Em primeiro lugar, o gráfico nos dá a importância das aplicações em títulos e valores mobiliários para este grupo, que superam as operações de empréstimos e financiamentos, em termos de proporção do ativo, no período que vai de 1992 a 1999. Durante o período que vai de 1989 a 1994, a trajetória do indicador de rentabilidade do ativo parece ser resultado de uma ação conjunta dos três indicadores: Tvm/Ativo, Emp/Ativo e Financ/Ativo. Nota-se que, a partir de 1994, a aquisição 
de títulos como proporção do ativo apresenta um enorme salto, o que pode ser explicado pelo crescimento das taxas de juros no período pós-estabilização. A trajetória é crescente até 1997 - quando estoura a crise asiática - e daí em diante os bancos, fugindo da crise cambial, desfazem-se dos papéis comprados durante o período 1994-1997. Percebe-se que a trajetória da rentabilidade do ativo é crescente durante todo o período (1994-1999), o que pode ser um resultado da estratégia bancária de manipulação dos títulos públicos. A partir de 2000, a trajetória do Lucro/Ativo torna-se irregular e parece ser mais guiada pelas operações de empréstimo, como também pode ser explicada por questões de conjuntura ou, ainda, por aplicações não analisadas neste trabalho.

\section{Considerações Finais}

A análise combinada dos indicadores analisados na seção anterior permite concluir que, no período pós-estabilização, houve uma realocação do volume de crédito concedido em Minas Gerais com benefício para as cidades de pequeno e médio porte, principalmente no que tange aos empréstimos de curto prazo. Dessa forma, percebe-se uma influência direta dos empréstimos na rentabilidade do ativo dos municípios mineiros, influência essa que parece ser tanto maior quanto menos desenvolvido economicamente é o município. Essa afirmação é sustentada pela constatação de que, nos municípios de médio porte, o comportamento do lucro/ativo parece mais correlacionado com a trajetória do volume de financiamentos como proporção do ativo. Além disso, percebe-se que na microrregião de Belo Horizonte a tendência do Lucro/Ativo ao longo do período analisado é mais complexa e não pode ser compreendida apenas com os indicadores analisados. Contudo, nesses municípios as aplicações em títulos e valores mobiliários têm um peso importante e, durante o período que vai de 1994 a 1999, o indicador Tvm/Ativo parece ser a variável mais importante para compreender a trajetória dos lucros como proporção do ativo.

Os indicadores analisados ao longo do trabalho revelam um sistema financeiro bastante concentrado, com estratégias distintas no espaço e com uma alta capacidade de adaptação a diferentes conjunturas econômicas. No que tange aos retornos do setor, nota-se que os municípios menos desenvolvidos apresentam os maiores lucros em termos do ativo, principalmente no período pós-estabilização. Estes resultados são claramente guiados pela concessão de empréstimos de curto prazo, os quais possuem uma rentabilidade, como proporção do volume de recursos aplicado, superior aos financiamentos. Contudo, o empréstimo, por tratar-se de um crédito de menor prazo, cuja finalidade precípua é, via de 
regra, o consumo, tem pouca importância no que tange ao desenvolvimento econômico regional.

Ao longo do trabalho também foi possível notar que as regiões menos desenvolvidas possuem trajetórias mais instáveis para os indicadores observados, o que pode ser justificado pelo fato de o sistema financeiro, em períodos de crise, realocar suas aplicações para os municípios mais desenvolvidos, onde o risco das operações é menor.

Todas essas afirmações confirmam a hipótese da existência de estratégias bancárias diferenciadas por regiões. Embora exista uma linha mais geral de atuação dos bancos, respondendo ao contexto macroeconômico, as evidências apontam para o fato de essa atuação mais geral ser aplicada em diferentes regiões com intensidades distintas. Tal estratégia, no entender dos autores, tem implicações muito importantes para o desempenho econômico dos municípios mineiros, atuando no sentido de aprofundar as desigualdades regionais.

\section{Referências}

ALMEIDA, D. B. C. Bancos e concentração de crédito no Brasil: 1995-2004. 90f. 2007. Dissertação (Mestrado em Economia) - Centro de Desenvolvimento e Planejamento Regional, Faculdade de Ciências Econômicas, Universidade Federal de Minas Gerais, Belo Horizonte, 2007.

AMADO, A. A questão regional e o sistema financeiro no Brasil: uma interpretação pós keynesiana. Estudos econômicos, v. 27, n. 3, p. 417-40, 1997.

. Moeda, financiamento, sistema financeiro e trajetórias de desenvolvimento regional desigual: a perspectiva pós-keynesiana. Revista de Economia Política, v. 18, n. 1, jan./ mar. 1998.

ARAÚJO, L. A. et al. Competição e concentração entre os bancos brasileiros. In: ENCONTRO DE ECONOMIA DA REGIÃO SUL, v. 8, 2005, Porto Alegre. Anais... Porto Alegre: ANPEC-SUL, 2005. [1 CD-ROM].

ARESTIS, P.; DEMETRIADES, P. Financial development and economic growth: assessing the evidence. Economic Journal, v. 107, n. 442, p. 783-99, may 1997.

ASSOCIAÇÃO BRASILEIRA DAS ENTIDADES DO MERCADO FINANCEIRO E DE CAPITAIS/INSTITUTO BRASILEIRO DE GEOGRAFIA E ESTATÍSTICA (ANDIMA/ IBGE). Sistema financeiro: uma análise a partir das Contas Nacionais 1990-1995. Rio de Janeiro: Andima, 1997.

BARBACHAN, J. S. F.; FONSECA, M. M. Concentração bancária brasileira: uma análise microeconômica. São Paulo: IBMEC, 2004.

BRASIL. Presidência da República. Secretaria de Assuntos Estratégicos. Ipeadata. Disponivel em http://www.ipeadata.gov.br. Acesso em 17 ago. 2008.

CARVALHO, C. E.; STUDART, R.; ALVES JR., A. J. Desnacionalização do setor bancário e financiamento das empresas: a experiência brasileira recente. Texto para Discussão: IPEA. Brasília, n. 882, 2002. 
CAVALCANTE, A. Financiamento e desenvolvimento local: um estudo sobre arranjos produtivos. Dissertação (Mestrado em Economia) - Centro de Desenvolvimento e Planejamento Regional, Faculdade de Ciências Econômicas, Universidade Federal de Minas Gerais, Belo Horizonte, 2006.

CORAZZA, G. Crise e reestruturação bancária no Brasil. Revista Análise. Porto Alegre, v. 12, n. 2, p. 21-42, 2001.

CROCCO, M. et al. The behaviour of liquidity preference of banks and public and regional development: the case of Brazil. Journal of Post Keynesian Economics, New York, v. 28, n. 2, p. 217-240, 2005.

CROCCO, M.; JAYME JR. O ressurgimento da geografia da moeda e do sistema financeiro. In: CROCCO, M.; JAYME JR., F. (Org.). Moeda e território: uma interpretação da dinâmica regional brasileira. Belo Horizonte: Autêntica, 2006.

CROCCO, M.; SANTOS, F. Financiamento e desenvolvimento sob novas óticas. In: A Arquitetura da Exclusão. Relatório anual do Observatório da Cidadania. Rio de Janeiro, 2006. Disponível em http://www.ibase.br/modules.php?name=ConteudoEspid=1622. Acesso em 17 de ago. 2008.

DEMETRIADES, P. O.; HUSSEIN, K. A. Does financial development cause economic growth? Time series evidence from 16 countries. Journal of Development Economics, v. 51, n. 2, p. 387-411, dec.1996.

DOW, S. The regional composition of the money multiplier process. Scottish Journal of Political Economy. v. 19, n. 1, 1982.

Financial markets and regional economic development: the Canadian experience. Aldershot: Averbury, 1990. Money and the economic process. Aldershot: Elgar, 1993.

The stages of banking development and the spatial evolution of financial systems. In: MARTIN, R. (Ed.). Money and the space economy. Londres: Willey, 1998.

FAINI, R. et al. Finance and development: the case of Southern Italy. In: GIOVANNINI, A. (Ed.). Finance and development: issues and experience. Cambridge: Cambridge University Press, 1993.

GERTLER, M.; ROSE, A. Finance, public policy and growth. In: CAPRIO, G.; ATILJAS, I.; HANSON, J. A. (Ed.). Financial Reform: theory and experience. Cambridge: Cambridge University Press, p. 13-45, 1996.

INSTITUTO BRASILEIRO DE GEOGRAFIA E ESTATÍSTICA. Contas regionais. Brasília: IPEA. Disponivel em http://www.ipeadata.gov.br/ipeaweb.dll/ipeadata?SessionID $=20$ $02127317 \mathcal{E}$ Tick $=1282085415384 \mathcal{E}$ VAR_FUNCAO $=$ Ser_TemasNiv $(127,5) \mathcal{E} \mathrm{Mod}=\mathrm{R}$. Acesso em 17 de ago. 2008.

JAYARATNE, J.; STRAHAN, P. E. The finance-growth nexus: evidence from bank branch deregulation. Quartely Journal of Economics, v. 111, n. 3, p. 639-70, aug. 1996.

KING, R. G.; LEVINE, R. Finance and growth: Schumpeter might be right. Quarterly Journal of Economics, v. 108, n. 3, p. 717-38, 1993 a.

Finance, entrepreneurship, and growth: theory and evidence. Journal of Monetary Economics, v. 32, n. 3, p. 513-42, 1993b. 
Financial intermediation and economic development. In: MAYER, C.; VIVES, $\overline{\mathrm{X}}$. (Ed.). Capital markets and financial intermediation. Cambridge: Cambridge University Press, p. 156-189, 1993c.

LABORATÓRIO DE ESTUDOS EM MOEDA E TERRITÓRIO (LEMTE/Cedeplar/UFMG). (Banco de dados).

LEVINE, R. Financial development and economic growth: views and agenda. Journal of Economic Literature, v. 35, n. 2, p. 688-726, jun.1997.

. The legal environment, banks and long-run economic growth. Journal of Money Credit and Banking, v. 30, n. 3, p. 596-613, 1998.

MOORE, C. L.; HILL, J. M. Interregional arbitrage and the supply of loanable funds. Journal of Regional Science, v. 22, p. 499-512, 1982.

MYRDAL, G. Teoria Econômica e regiões subdesenvolvidas. Rio de Janeiro: ISEB, 1960.

PEREIRA, F. M. Cidades médias brasileiras: uma tipologia a partir de suas (des)economias de aglomeração. Dissertação (Mestrado em Economia) - Centro de Desenvolvimento e Planejamento Regional, Faculdade de Ciências Econômicas, Universidade Federal de Minas Gerais, Belo Horizonte, 2002.

PUGA, F. P. Sistema financeiro brasileiro: reestruturação recente, comparações internacionais e vulnerabilidade à crise cambial. Texto para Discussão: BNDES, Rio de Janeiro, n. 68, 1999.

RAJAN, R. G.; ZINGALES, L. Financial dependence and growth. American Economic Review, v. 88, n. 3, p. 559-86, jun. 1998.

ROBERTS, R. B.; FISHKIND, H. H. The role of monetary forces in regional economic activity: an econometric simulation analysis. Journal of Regional Science, v. 19, n. 1, p. 15-29, 1979.

RODRIGUEZ-FUENTES, C. J. Credit availability and regional development. Papers in Regional Science, v. 77, n. 1, p. 63-75, 1998.

. Regional Monetary Policy. Routledge: Abingdon, 2006.

SAMOLYK, K. A. Banking conditions and regional economic performances. Journal of Monetary Economics, v. 34, p. 259-78, 1994.

SOARES, R. P. Evolução do crédito de 1994 a 1999: uma explicação. Texto para Discussão: IPEA, Rio de Janeiro, n. 808, 2001.

WORLD BANK; INTERNATIONAL MONETARY FUND. Financial sector assessment: a handbook. Washington: Word Bank; International Monetary Fund, 2005.

Recebido em: 12/02/2009.

Aceito em: 07/08/2009. 